\title{
Examining the Causal Relationship between Private Sector Credit Extended and Economic Growth in Namibia
}

\author{
Andreas $^{1}$,J P S Sheefeni ${ }^{2}$ \\ ${ }^{1}$ Department of Economics, University of Namibia, Namibia \\ ${ }^{2}$ Department of Economics, University of the Western Cape, South Africa \\ peyavali@gmail.com
}

\begin{abstract}
The paper examined causality between Private Sector Credit Extension (PSCE) and Economic growth using quarterly data for the period 2000:Q1-2017:Q4, in Namibia. The variables employed were Gross Domestic Product (GDP), Private Sector Credit Extended, Broad Money Supply (M2) and lending rates. The study tested for stationarity in order to determine the order of integration. Furthermore, a co-integration test was conducted on different sets of variables to establish the long run relationship. Granger causality test was also conducted to establish the direction of the relationships between the variables. The results for the stationarity test showed a combination of different orders of integration. The co-integration test revealed a stable long-run relationship among the variables. The Granger causality test results revealed one-directional causality running from PSCE to GDP. Therefore, one can conclude that that change in private sector credit extended can help predict economic growth.
\end{abstract}

Keywords: Credit growth, economic growth, unit root, co-integration, Granger causality

\section{Introduction}

The capability of economic growth is usually used as a yardstick in gauging economic performance. Economic growth is explained as an increase in the real Gross Domestic Product (GDP) of a country (Gerber, 2009). A rise in real GDP simply means an increase in factor inputs used in the production process by businesses (Ashipala and Haimbodi, 2003). Since the attainment of independence in 1990, there has been positive growths in the Namibian with the exception of 1993 were negative growth was experienced. This was due to diamond production cuts in response to De Beers stockpiling (Sherbourne, 2010). In addition, Namibia has constant economic growth for total production in real GDP terms ever since 1990. The annual growth rates experienced between 1996 and 2000 were between 3.2\% and 4.2\% respectively (Central Bureau of Statistics [CBS], 2000). Thus, economic growth rate for the 18 years has averaged a positive growth rate of $5 \%$. However, for the years 2004 and 2006, Namibia recorded the highest growth rate of $12.3 \%$ and $7.1 \%$, respectively.

The high growth rate for the year 2004 and 2006 was mainly driven by the diamond-mining sub-sector (CBS, 2000-2007). The report further mentioned that the years 2001, 2009 and 2016 recorded the lowest growth rates of $1.2 \%, 0.3 \%$, and $1.1 \%$, respectively. Gerber (2009) defined credit as the money to the borrowers from the lenders. Private Sector Credit Extended (PSCE) in Namibia is credit extended to both businesses and household sectors. There are six types of credit categories, which can be either extended to businesses and household sectors namely: Mortgage loans, Overdraft, Instalment credit, other loans and advances, Leasing and others (Bank of Namibia Annual report, 2015). Private Sector Credit Extended (PSCE) in Namibia showed a fastened pace growth in recent past few years, though reached the highest growth rate of $18.0 \%$ on average in 2006. However, as experienced elsewhere in the world, the 2008/2009 financial crisis took its toll on the growth of credit extended. In response, the central bank, Bank of Namibia was cautionary in maintaining an accommodating monetary policy standpoint during 2009 as the economic crisis intensified and further spread.

In particular, the monetary authority reduced the key policy rate, the repo rate to $7 \%$ in December 2009 from 10\% in December 2008 (Bank of Namibia Annual report, 2009). The reduction in interest rates did not stimulate domestic demand as it was reflected in indicators such as the decelerating of private sector credit extension as well as a fall in motor vehicle sales (Bank of Namibia Annual report, 2009). Thereafter, growth in PSCE picked up at a faster pace as it continued to be in the double-digit (Bank of Namibia, 2015). Thus, the central bank had increased the key policy twice within a space of four months in 2014 and early 2015. These acts the monetary authorities were aimed at containing the persistence high growth in household credit, 
specifically overdraft and instalments credit (Bank of Namibia, 2014). The obvious question that follows is whether the rise in the repo rate in containing credit would not depress economic growth.

The working of private sector credit extension has implications for economic growth through financial development. For instance, it is argued that economies with well-functioning banking and financial sector experience faster growth. The reason for this argument is attributed to the ability of better financial systems in alleviating external financing constraints that impede businesses as well as industrial expansion and subsequently growth (Mishkin, 2007). In other words, this smoothens the credit extension and results in growth. However, others also argue that it is high GDP growth that leads to an increase in demand for credit due to a rise in demand in goods and services (Martynova, 2015). It is because of this contestation on the causality question between private sector credit and economic growth this study draws its primary interest. Therefore, the objective of the study is to examine the causality among the variables. The paper is structured as follows: the next section presents a literature review. Section 3 discusses the methodology. The empirical analysis and results are presented in section 4 . Section 5 concludes the study.

\section{Literature Review}

Literature has shown that bank credit availability plays an important part in stimulating economic growth. More so, it has also been shown that economic growth is also essential for growth in credit as demand for goods and services. Thus, according to Yakubu and Affoi (2013), there is an established fundamental relationship between credit and economic growth through financial intermediation. Thus, credit extension is an important function of financial intermediation that ensures the provision of funds to economic entities that channel them to productive use. That is why Spencer (1977) argued that the involvement of banks in financial intermediation process automatically links credit and GDP growth because it is almost impossible to separate credit from banks. Specifically, banks are creditors to those seeking funds and debtors to those depositing or lending funds. Thus, credit extension by banks is referred to as the borrowing capacity by the banking system in the form of loans provided to an individual, government, firm or organization. It is for this reason; it is argued that credit availability enables the function of financial intermediation to be intact and subsequently spills over to economic growth. Numerous studies have empirically looked at the relationship between credit and economic growth. In Namibia, there are two related studies.

The first study was by Mushendami (2007) who investigated the relationship between financial development and economic growth in Namibia for the period 1993 to 2005 using time-series quarterly data. Time-series techniques such as unit root, cointegration, error correction modelling (ECM) and Granger-causality test approaches were used. The main findings of the study revealed a one-directional causal relationship, running from GDP to financial development variables (private sector credit extended was among those). This suggests that GDP growth stimulates demand for credit in the economy. A second study was conducted by Sindano (2009) who also investigated causality between the two variables similar to that of Mushendami (2007), for the period 1993 to 2007. The long-run relationship was examined using a cointegration test. Causality among the variables was analysed using the Granger causality test. The findings showed a stable long-run relationship among the variables. The results for the causality test revealed a unidirectional causal relationship running from economic growth to financial development (private sector credit extended was one of the variables). As it is the case with Mushendami's study, this study also implies or advocates for real sector growth to further stimulate demand for credit. From the Asian continent, Mishra, Das and Pradhan (2009) use the vector autoregression to determine the nature of the relationship between credit market development and economic growth in India.

The authors also employed the Granger-causality among the variables for the period 1980 to 2008. The findings revealed a one-directional causal relationship from credit market to economic growth. This implies that credit market can be used to predict economic growth. In other African countries, Haruna, Yahya and Nasiru (2013) employed the autoregressive distributed lag (ARDL) model on the study on Nigeria. The authors also employed causality test between private sector credit and economic growth on the data for the period of 37 years (1974-2010). The finding showed a long-run relationship among the variables. However, causality test showed no presence of causality. The absence of causality implies that the two variables are independent and thus, cannot be used to predict each other. In Cameroon, Belinga and Doumbe (2016) 
examined causality between bank credit and economic growth. In this study, unit root, cointegration and causality tests were employed on data covering the period 1969 - 2013. The findings revealed a onedirectional causality running from domestic credit to the private sector and Bank deposits to economic growth.

Similarly, Okafor, Chijindu and Ugochukwu (2016) employed the Granger-causality test to assess the causality between bank credit and economic growth in Nigeria for the period 1981-2014. Similar to the previous study, the main findings revealed a one-directional causal relationship running from private sector credit and broad money supply to economic growth. This shows that private sector can be used to predict economic growth. Furthermore, these findings affirm the significance and importance of bank credit availability to economic growth. In Jordan, Ananzeh (2016) employed the vector error correction model (VECM) and Grangercausality tests on the dataset for the period 1993 to 2014. The main findings revealed a long-run relationship between real GDP and total bank credit while the Granger-causality results showed unidirectional causality running from economic growth to bank credit at agriculture and construction sectors in Jordan economy. Moreover, the bi-directional causality was witnessed between economic development and bank credit.

Similarly, in selected Middle-East and North African (MENA) countries, Puryan (2017) employed the Grangercausality test to examine the causal relationship between economic growth, banking sector development, and stock market development (SMD) for the period 1988-2012. The Granger-causality results revealed a unidirectional causal relationship running from banking sector development to economic growth. Furthermore, a bi-directional causality between SMD and economic growth was also established and unidirectional causality running from banking sector development toward stock market. In terms of Namibia's literature, the earlier study by Mushendami (2007) and Sindano (2012) have a time lapse in that between then and now a lot might have changed. Thus, it calls for renewed study with more recent data. Most studies that were conducted thereafter only focused on determinants of private sector credit extended. Therefore, the study intends to fill this literature gap.

\section{Methodology}

Econometric Framework and Model Specification: In analysing the causal relationship between Private Sector Credit Extended and Economic growth in Namibia, the study followed Akpansung and Babalola (2011) approach. The reason for choosing this approach is based on the fact that when the variables involved are non-stationary but cointegrated, a classic Granger causality cannot be performed because the results will be unreliable (Enders, 2010). Therefore, causality test is conducted within the VECM framework. Thus, firstly, since the study used the time series data, they will be subjected to a unit root test by employing the Augmented Dickey-Fuller (ADF) and Philips and Peron (PP). Secondly, the study engaged a cointegration test to establish the existence of the presence of the long-run relationship. The presence of the cointegration suggests an estimation of a VECM model and also further suggests a possibility of a causal relationship at least in one direction. Lastly, the Granger causality test was performed in order to establish the direction of the causal relationship. The variables employed in the study were: GDP growth (Y), PSCE growth (Dc), lending rate (L) and Broad money supply, while W is the error correction term. Thus, the VECM model was specified as follows:

$Y_{t}=\beta_{10}+\sum_{i=1}^{k} \beta_{11, i} Y_{t-i}+\sum_{i=1}^{k} \beta_{12, i} D c_{t-i}+\sum_{i=1}^{k} \beta_{13, i} L_{t-i}+\sum_{i=1}^{k} \beta_{14, i} M 2_{t-i}+\theta W_{t-1}+\xi_{1 t}$

$D c_{t}=\beta_{20}+\sum_{i=1}^{k} \beta_{21, i} Y_{t-i}+\sum_{i=1}^{k} \beta_{22, i} D c_{t-i}+\sum_{i=1}^{k} \beta_{23, i} L_{t-i}+\sum_{i=1}^{k} \beta_{24, i} M 2_{t-i}+f W_{t-1}+\xi_{2 t}$

Data Measurements and Data Sources: Quarterly dataset for the period 2000:Q1-2017:Q4 was used. The variables are: Gross Domestic Product growth rate (Y), Private Sector Credit Extended growth rate (Dc), Lending rate (L) and Broad money supply (M2). The period chosen is dictated by availability of data. Particularly, data for the private sector only starts from the year 2000. All the dataset were sourced from the annual and quarterly reports of the Bank of Namibia and National Accounts from Namibia Statistics Agency. 


\section{Empirical Results and Findings}

Unit Root Test: The initial step was to test for unit root in order to determine the order of integration. In this regard, the Augmented Dicker-Fuller (ADF) and Philips Peron (PP) test statistics were applied to test the presence of unit root. Both trend and intercept were included in the test equations for all the variables using the two test types. Table 1 below summarizes the results.

Table 1: Unit Root Tests: ADF and PP in levels and First Differences

\begin{tabular}{|c|c|c|c|c|c|c|}
\hline Variable & $\begin{array}{l}\text { Model } \\
\text { specification }\end{array}$ & $\begin{array}{l}\text { ADF } \\
\text { Levels }\end{array}$ & $\begin{array}{l}\text { PP } \\
\text { Levels }\end{array}$ & $\begin{array}{l}\text { ADF } \\
\text { First } \\
\text { difference }\end{array}$ & PP & Order of integration \\
\hline \multirow{2}{*}{$\mathbf{Y}$} & Intercept and Trend & $-6.565^{* *}$ & $-6.688^{* *}$ & $-7.116^{* *}$ & $-20.736^{* *}$ & 0 \\
\hline & Intercept & $-6.545^{* *}$ & $-6.667 * *$ & $-7.128 * *$ & $-20.752^{* *}$ & 0 \\
\hline \multirow{2}{*}{ DC } & Intercept and Trend & -2.069 & $-5.013^{* *}$ & $-7.034^{* *}$ & $-13.053^{* *}$ & 1 \\
\hline & Intercept & -1.338 & $-4.378^{* *}$ & $-6.966^{* *}$ & $-13.026^{* *}$ & 1 \\
\hline \multirow{2}{*}{$\mathbf{L}$} & Intercept and Trend & -1.730 & -1.896 & $-7.312^{* *}$ & $-7.314^{* *}$ & 1 \\
\hline & Intercept & -1.726 & -1.726 & $-7.265^{* *}$ & $-7.275^{* *}$ & 1 \\
\hline \multirow[t]{2}{*}{ M2 } & Intercept and Trend & $-3.526^{* *}$ & $-3.660^{* *}$ & $-8.439 * *$ & $-8.455^{* *}$ & 0 \\
\hline & Intercept & $-3.486^{* *}$ & $-3.619 * *$ & $-8.501^{* *}$ & $-8.519 * *$ & 0 \\
\hline
\end{tabular}

Source: Author's computation and values obtained from E-views

Note: ${ }^{* *}$ represent stationary at 5 percent level

Table 1 report that the variables were non-stationary in level form, except for economic growth (Y) and money supply whose results were stationary in level form. Therefore, all the non-stationary variables in level form were converted to become stationary after differencing them once, meaning they are integrated of order 1.

VAR Stability: Testing for stability in levels indicated that the VAR is stable in levels, (as can be seen in the graph) this indicates the VAR in level form fulfils the requirement of the stability condition.

Table 2: VAR Stability

\begin{tabular}{ll}
\hline Root & Modulus \\
\hline 0.942982 & 0.942982 \\
0.731189 & 0.731189 \\
$0.626062-0.363505 \mathrm{i}$ & 0.723940 \\
$0.626062+0.363505 \mathrm{i}$ & 0.723940 \\
$-0.359277-0.161669 \mathrm{i}$ & 0.393976 \\
$-0.359277+0.161669 \mathrm{i}$ & 0.393976 \\
0.151587 & 0.151587 \\
-0.072956 & 0.072956
\end{tabular}

No root lies outside the unit circle.

VAR satisfies the stability condition.

Source: Author's computation and values obtained from E-views

Determination of Optimal Lag Length: The VAR model includes variables that are lagged. It is for this reason that an optimal number of lags had to be determined. This was done in order to avoid either specifying 
too many lags or too few lags for the model. The implication of overstating or understating number of lags has consequences on the results thereof. More so, Granger causality is sensitive to lags specified in the model.

Table 3: Lag Length Criteria

\begin{tabular}{lllllll}
\hline Lag & Log L & LR & FPE & AIC & SC & HQ \\
\hline 0 & -787.2629 & NA & 304420.7 & 23.97766 & 24.11037 & 24.03010 \\
1 & -665.5166 & 225.0463 & $\mathbf{1 2 3 6 8 . 2 2 *}$ & $\mathbf{2 0 . 7 7 3 2 3} *$ & $\mathbf{2 1 . 4 3 6 7 6 *}$ & $\mathbf{2 1 . 0 3 5 4 2 *}$ \\
2 & -652.0457 & 23.26786 & 13429.39 & 20.84987 & 22.04423 & 21.32182 \\
3 & -642.4531 & 15.40633 & 16537.60 & 21.04403 & 22.76922 & 21.72574 \\
4 & -622.3467 & $\mathbf{2 9 . 8 5 4 9 7 *}$ & 14996.38 & 20.91960 & 23.17561 & 21.81105 \\
5 & -608.1387 & 19.37450 & 16546.36 & 20.97390 & 23.76073 & 22.07511 \\
6 & -594.4098 & 17.05719 & 18959.48 & 21.04272 & 24.36038 & 22.35369 \\
\hline
\end{tabular}

Note: * implies selection of optimal lag length.

Source: Author's computation and values obtained from E-views

Table 3 shows the lag length structure and the convergence lag length suggested by the lag length criterion is ones. This is what the majority criterion suggested. However, the suggested optimal lag length is also by the two most commonly followed criterions in literature, the AIC and SIC.

\section{Cointegration Test}

Table 4: Johansen Cointegration Test Based on Trace and Maximum Eigen Values

\begin{tabular}{llllllll}
\hline Trace Test & \multicolumn{5}{c}{ Maximum Eigen Test } \\
\hline Ho: rank=r & Ha: rank=r & Statistic & $\begin{array}{l}95 \% \\
\text { critical } \\
\text { value }\end{array}$ & Ho: rank=r & Ha: rank=r & Statistic & $\begin{array}{l}95 \% \\
\text { critical } \\
\text { value }\end{array}$ \\
$r=0$ & $\mathrm{r}=0$ & 52.84942 & 47.85613 & $\mathrm{r}=0$ & $\mathrm{r}=0$ & 23.49176 & 27.58434 \\
$\mathrm{r}<=1$ & $\mathrm{r}<=1$ & 29.35767 & 29.79707 & $\mathrm{r}<=1$ & $\mathrm{r}<=1$ & 19.87389 & 21.13162 \\
$\mathrm{r}<=2$ & $\mathrm{r}<=2$ & 9.483773 & 15.49471 & $\mathrm{r}<=2$ & $\mathrm{r}<=2$ & 6.252884 & 14.26460 \\
$\mathrm{r}<=3$ & $\mathrm{r}<=3$ & 3.230889 & 3.841466 & $\mathrm{r}<=3$ & $\mathrm{r}<=3$ & 3.230889 & 3.841466 \\
\hline
\end{tabular}

Note: Trace test indicates one (1) integrating equations at 5\% level whilst Max-eigenvalue test indicates no cointegration at the 0.05 level.

Source: Author's computation and values obtained from E-views

Table 4 presents the findings for the Johansen Cointegration test based on trace and maximum Eigenvalue statistics. Trace test shows that there is one cointegrating equation while Max-eigenvalue test shows no cointegration at the 0.05 level. Given the conflict between the two tests, the study considered the trace test because it is more powerful. The trace test statistics calculated values are larger than the critical values hence, rejecting the null hypothesis of no cointegration of variables at $5 \%$ and concluding that there is cointegration. Thus, in the presence of cointegration suggest that a VECM model to be estimated from which the Granger causality was derived from. The findings of the study have implications for the operations of the central bank and as well as other agents in the monetary sector.

Granger Causality: One of the major usefulness of VAR models is their ability to forecast (predict). Thus, the structure of the VAR model presents the information about a series' or a group of series' ability to predict to forecast other series. If a series, or group of series, $Y_{1}$ is helpful in forecasting another series, or group of series, $Y_{2}$ then $Y_{1}$ is said to Granger-cause $Y_{2}$ (Emecheta and Ibe, 2014). 
Table 5: Granger Causality Test

\begin{tabular}{lllll}
\hline \multirow{2}{*}{ Regressor } & \multicolumn{2}{l}{ Dependent Variable in Regression } & \multicolumn{2}{l}{ M2 } \\
\hline Y & Y & DC & L & 0.4127 \\
DC & - & 0.3557 & 0.6754 & 0.9249 \\
L & $0.0012^{* *}$ & - & 0.7242 & 0.0455 \\
M2 & 0.6499 & 0.9506 & - & - \\
\hline
\end{tabular}

Source: Author's computation and values obtained from E-views Note: ${ }^{* *}$ represent 5 percent level of significance

Table 5 summarizes the Granger causality results for the three variables. The results show that PSCE can help to predict the GDP. Similarly, M2 can help to predict GDP.

PSCE and Economic Growth: This means that private sector credit extended can help to predict economic growth in Namibia. The possible explanation could be that when PSCE increased, this an indication of high spending in the economy and thus contributing positively to the economy. Although high demand for private sector credit extended has a positive impact on the economic growth, it is a concern in Namibia because this high demand for PSCE emanated from the household sector and these can become a problem. These findings are same as that of Emechata and Ibe (2014), that there is an un-directional causal relationship between the PSCE and GDP.

M2 and Economic Growth: The result indicated that broad money supply could help to predict economic growth. As it was stated earlier, money supply is one of the determinants of domestic claims, hence, domestic claims include the claims on the sectors (this include PSCE) and claims on central government. Therefore, any movement in the broad money can only be caused by; either changes in domestic claims or net foreign assets. This means that for instance if M2 growth increases due to domestic claims this is an indication that economic growth increases too and vice versa. The results revealed that there is no causality between Economic growths and lending rates and vice versa as well as between Lending rates and PSCE.

\section{Conclusion}

This study examined the causal relationship between private sector credit extended and economic growth in Namibia using quarterly data from 2000-2017. The study employed the Granger causality test within the vector error correction framework. The study employed other time-series technique such as unit root test, cointegration to examine long-run relationships. Granger causality test was the last test to establish the direction of the relationship between variables used. The results indicate a stable long-run relationship between the variables, with GDP being the dependent variable and the rest, the regressors. The results further indicate that there is a unidirectional causality running from credit growth to economic growth, as well as from broad money supply to economic growth. The study tries to enlighten authorities that PSCE growth is good for the economy but needs to be monitored and as such it is of utmost importance that regulatory authorities constantly.

Monitor developments in credit aggregates on a regular basis as it, not only movements in credit instruments that influence the direction but developments in broad money supply as well. The findings of the study have implications for the operations of the central bank and as well as other agents in the monetary sector. For the Bank of Namibia, the rate of growth in Private Sector Credit Extended is one of the operative variables used to inform monetary policy decision. Against that background, the findings of this study, therefore, have a bearing on the ability of the Bank of Namibia to attain its primary objective maintaining price stability through monetary policy conduct. Therefore, the study recommends that monetary authority to be cautious in controlling credit extension as it serves as a lifeline to further demand for goods and services which is basically stimulation of economic activities and subsequently economic growth. 


\section{References}

Akpansung, A. O. \& Babalola, S. J. (2011). Banking Sector Credit and Economic Growth in Nigeria: An Empirical Investigation. CBN Journal of Applied Statistics, 2(2), 52-62.

Ananzeh, I. E. N. (2016). Relationship between Bank Credit and Economic Growth: Evidence from Jordan. International Journal of Financial Research, 7(2), 53-63.

Ashipala, J. \& Haimbodi, N. (2003). The impact of Public Investment on Economic Growth in Namibia, Namibia Economic Policy Research Unit Working Paper No. 88

Bank of Namibia. (2009). Annual Report. Windhoek.

Bank of Namibia. (2014). Monetary Policy Stance, August 2014. Windhoek.

Bank of Namibia. (2015). Annual Report. Windhoek.

Belinga, T. \& Doumbe, E. (2016). Causality Relationship between Bank Credit and Economic Growth: Evidence from a Time Series Analysis on a Vector Error Correction Model in Cameroon. School of Economics, Wuhan University of Technology, China.

Central Bureau of Statistics. (2000-2007). National Accounts. Windhoek.

Emecheta, B. C. \& Ibe, R. C. (2014). Impact of Bank Credit on Economic Growth in Nigeria. European Journal of Accounting Auditing and Finance Research, 2(9), 11-21.

Enders, W. (2010). Applied Econometric Times Series (3rd Ed), Wiley.

Gerber, M. (2009). Principles of Economics, Polytechnic of Namibia. Windhoek.

Haruna, M. A., Yahya, Z. A. \& Nasiru, A. (2013). Private Sector Credit and Economic Growth Nexus in Nigeria: An Autoregressive Distributed Lag Bound Approach. Department of Economics, Usman Danfodiyo University, Sokoto.

Martynova, N. (2015). Effect of Bank Capital Requirements on Economic Growth: A Survey. De Nederlandsche Bank, Netherlands

Mishkin, F. S. (2007). The Economics of Money and Financial Markets, Pearson/Addison Wesley.

Mishra, P. K., Das, K. B. \& Pradhan, B. B. (2009). Credit Market Development and Economic Growth in India. Middle Eastern Finance and Economics, 5, 92-106.

Mushendami, P. (2007). Financial development and Economic growth in Namibia. Master's thesis, University of Namibia, Windhoek.

Okafor, I. G., Chijindu, E. H. \& Ugochukwu, S. (2016). Relationship between Deposit Money Bank Credit and Economic Growth in Nigeria under a VAR G-Causality Environment. Department of Banking and Finance, Caritas University, Enugu.

Puryan, V. (2017). The Causal Relationship between Economic Growth, Banking Sector Development and Stock Market Development in Selected Middle-East and North African countries. International Journal of Economics and Financial Issues, 7(3), 575-580.

Sindano, A. (2009). The Direction of Causal Relationship between Financial Development and Economic Growth in Namibia. Master's thesis, University of Namibia, Windhoek.

Sherbourne, R. (2010). Guide to the Namibian Economy 2010, Institute for Public Policy Research, Windhoek, Namibia.

Spencer, H. M. (1977). Contemporary Macroeconomics (3rd Ed), Worth Publishers, New York.

Yakubu, Z. \& Affoi, A. Y. (2013). An Analysis of Commercial Banks' Credit on Economic Growth in Nigeria Department of Economics, Kaduna State College of Education, Gidan Waya, Kafanchan, Kadun State, Nigeria. 